\title{
Comparative constructions in old Romanian
}

\author{
Raluca Brăescu* \\ "Iorgu Iordan - Al. Rosetti" Institute of Linguistics, 13 Calea 13 Septembrie, 050711 Bucharest, Romania \\ Faculty of Letters, University of Bucharest, 5-7 Edgar Quinet St., 010017 Bucharest, Romania
}

\section{Article info}

History:

Received May 23, 2017

Accepted June 6, 2017

Published September 30, 2017

Key words:

adjective

degree operator

comparative complement

word order

roll-up movement

\begin{abstract}
In this paper, we analyse degree adjectival constructions in old Romanian texts. We focus on the comparative of superiority, taking into account in the first place the grammaticalization stage of the degree markers. The structures from the old texts contain polyfunctional units in competition; some of them enter a complex process of specialisation (mai 'more'), while others disappear (camai). Afterwards, we focus on the realizations of the comparative complement in the corpus analysed: prepositional phrases headed by the prepositions $c a$, decit, de 'than'. We want to see if we can establish any constraints in the use of these prepositions. We pay attention to the word order disharmonies encountered in the old texts. The configurations with pre-adjectival complements are related to the existence of certain relics of the non-configurational syntax in old Romanian.
\end{abstract}

\section{Introduction}

The comparison system is prototipically represented by a set of expressions containing a degree operator and denoting a relation between a reference point (a standard value or a comparison class) and the value of a referee (the degree to which an entity has a certain property). Certain configurations are generally accepted; they correspond to a well-known scale: comparative of superiority (mai ... decit / ca 'more... than'), comparative of inferiority (mai puțin ... decît / ca 'less... than'), comparative of equality (la fel de / tot atît de / tot aşa de ... ca 'as... as'), relative superlative (cel mai ... din / dintre 'the most... of / among'). Traditionally, these values are considered to belong to an unique class, although they express different aspects of the intensity of a quality ((in)equality, parallelism, analogy, identity, proportion or measure variation).

Of the analyses available for comparative constructions, we adopt the one put forward by Kennedy (1999) with respect to gradable adjectives, defined as expressions of certain points on a semantic scale (relational expressions), because they link objects to the degrees of a specific scale. A scale is an abstract representation of a measure act, thus a dimensional parameter (a type of property) in which the order is regulated through degrees. Adopting a syntactic analysis, Kennedy (1999, p. 83) shows that the gradable adjectives project an extended functional structure headed by a degree morpheme.

In this paper, we aim to analyse comparative of superiority constructions in old texts (original texts and translations) from the $16^{\text {th }}$ and $17^{\text {th }}$ centuries ${ }^{1}$. In the diachronic studies on degree marking (Frâncu, 2009; Stan, 2013; Brăescu, 2015) it is shown that there are numerous items undergoing delexicalization, grammaticalization or re-analysis in order to become prototypical or emphatic means of expressing the category of comparison. In what follows, we take into account comparative configurations including adjectives, focusing on the status of the degree operator, the realizations of the comparative complement and the word order of the sequences involved in these constructions ${ }^{2}$.

\footnotetext{
*Email address: ralucabraescu@yahoo.com.

${ }^{1}$ The examples are taken from the corpus used for The Syntax of Old Romanian (Pană Dindelegan, 2016).

${ }^{2}$ The starting point of this paper is the postdoctoral study Degree and Intensity in Romanian. A diachronic and typological perspective, supported by the Sectorial Operational Programme Human Resources Development (SOP HRD), financed from the European Social Fund and by the Romanian Government under the contract number SOP HRD/159/1.5/S/136077.
} 


\section{The comparative of superiority}

In a full-fledged construction, the comparative of superiority links two items: the adjective (with the comparative morpheme) and the comparative complement. The degree operators attested in the old texts are: mai 'more' (< lat. MAGIS) ${ }^{3}$, the main marker used in the Latin analytic comparatives $(1 \mathrm{a}-\mathrm{f})$, and camai 'more' $(1 \mathrm{~g}-\mathrm{j})$ :

(1) a. Că mai bunră e domniia ta decî<t> that more good is reign your than

viiața mea (PH.1500-1510,51 $1^{\mathrm{v}}$ )

life my

'that your reign is better than my life'

b. Mai iubite-s decî<t> aurulu și piatra cea curată multă şi more loved=are than gold and stone that clean a.lot and mai dulce e de miiarea şi fagurul (PH.1500-1510,15 $\left.{ }^{\mathrm{r}}\right)$ more sweet is than honey.DEF and honeycomb.DEF

'They are more loved than gold and the clean large stone and it is sweater than honey and the honeycomb'

c. atunce cînd zua era mai caldă $(\mathrm{PO} .1582,56)$ then when day.DEF was more hot.F 'when the day was hotter'

d. lumina mai mică să slujască nopției (PO.1582, 13) light.DEF more $\operatorname{dim} \breve{S}_{\text {SUBJ }}$ serve night.DEF.DAT 'the dimmer light should serve the night'

e. mai multe şi mai greale sînt păcatele noastre $\left(\mathrm{CC}^{2} .1581,42\right)$ more a.lot and more burdensome are sins.DEF our 'our sins are more numerous and more burdensome'

f. Și vor hi ceia ce vor rămînea mai and AUX.FUt.3PL be.INF those who AUX.FUt.3PL remain.INF more

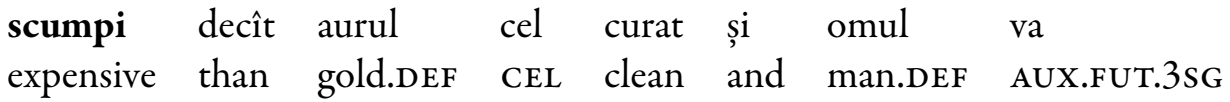
fi mai scump decît piatra zamfirul (DPar.1683, 31 ${ }^{\mathrm{v}}$ ) be.INF more expensive than stone sapphire

'And those who will remain will be more valuable than the clean gold, and man will be more valuable than the sapphire stone'

g. camai sărăcești și mai mici să sînt more poor and more small if are darurele noastre $\left(\mathrm{CC}^{2} .1581,124\right)$ gifts.DEF our 'if our gifts are poorer and smaller'

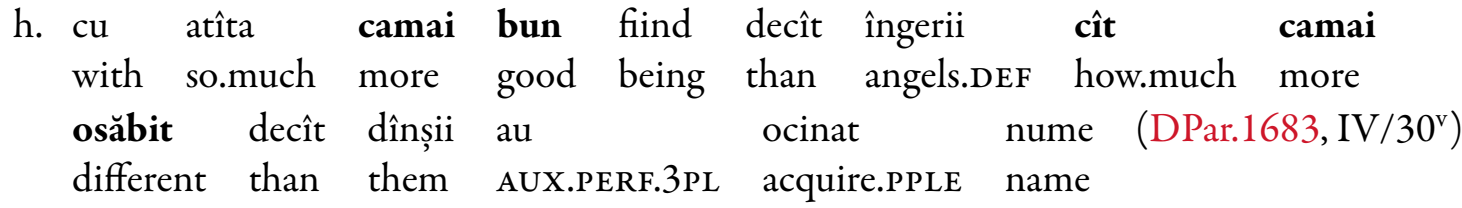

\footnotetext{
${ }^{3}$ Certain Romance languages also use the descendants of magis to express the comparative: Sp. más, Port. mais, Cat. mes, whereas others, like French and Italian, prefer plus (Fr. plus, It. piu). Moreover, there are varieties (such as Provençal) in which both forms, mais and plus are used (Lüder, 1996, p. 30). Similarly to old Romanian, old Romance is characterized by a high degree of variation. In old Spanish structures with plus are attested (since the $10^{\text {th }}$ century): plus áspero 'rougher'. Similar data related to the usage of plus were attested in old Catalan (pus).
} 
'being so much better than the angels that he acquired a better name than theirs'

i. Să-m faci acoperemîntul

$\breve{S A}_{\text {SUBJ }}=$ CL.DAT.1SG make.SUBJ.2sG roof.DEF

camai frumos (DVs.1682-6, 49 )

more beautiful

'you shall make my roof more beautiful'

j. Și făcea camai vîrtoase și mai trudite

and make.IMPERF more strong and more hard

rugile $\quad \mathrm{cu}$ dînşii (DVs.1682-6,209 $\left.{ }^{\mathrm{r}}\right)$

prayers.DEF with them

'and he made stronger and harder prayers with them'

The co-occurrence of certain forms having the same function, in similar structures and without precise combinatorial rules characterizes all the degree operators for the entire degree scale and it is, actually, a normal feature for an emerging system. The word mai changes from a lexical unit (an adverb) to a grammatical from (a comparative marker); however, this change does not affect the item camai (which disappears at a later stage).

The word mai is not grammaticalized as a marker for the comparative of superiority in old Romanian, a fact proved by is pre-nominal position ( $2 \mathrm{a}$ ) and by interpolation $(2 \mathrm{~b}-\mathrm{d})$. In fact, the entire adjectival phrase is pre-nominal, a pattern which has been gradually decreasing in frequency up to the present-day. The fact that mai (or camai) are not yet grammaticalized as degree markers is not only supported by word order freedom but also by their combination with amplified adverbs $(3 \mathrm{a}, \mathrm{b})$ or adjectives associated with downtoners (mai + destui 'enough') (3c).

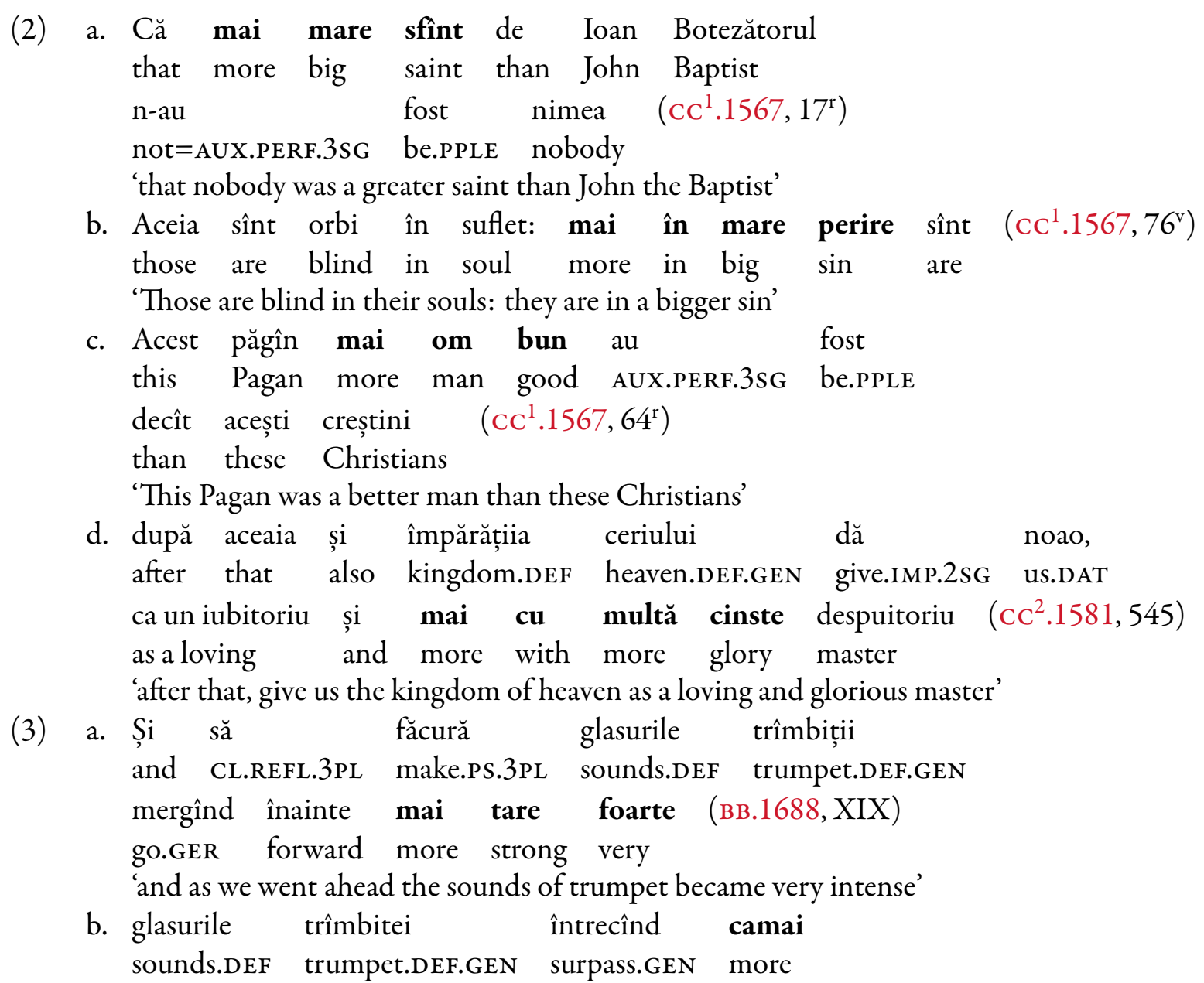




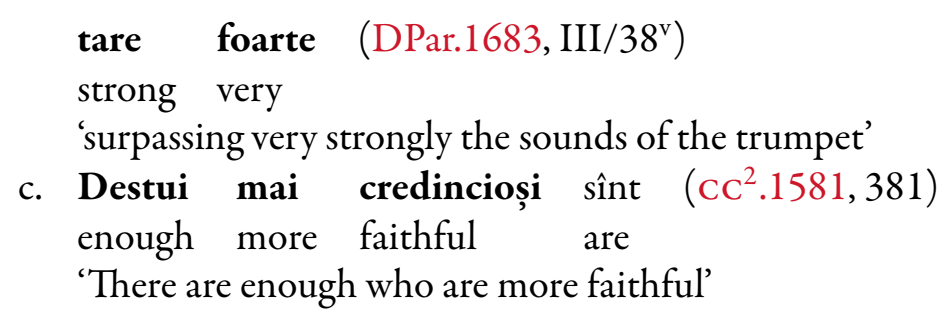

This unsystematic behaviour of comparative structures in the old language represents the reason for which certain linguists (Ciompec, 1985, p. 156) put forth the following periodization: in the first texts, the comparative construction "had a pre-morphological character" and it is only after the $17^{\text {th }}$ century that the first genuine lexicalized comparative constructions, with the present-day structure, were attested.

When combining with verbs, both mai and camai function as manner adverbs ('more') expressing the comparative by themselves (Ciompec, 1985, p. 155) in structures which disappeared from the modern language $(4 a-f)$. These structures illustrate an interesting phenomenon from a typological point of view. In Romanian, two parallel phenomena are at play: on the one hand, the texts show the ongoing specialization of the degree operator mai; on the other hand, the manner adverb mai progressively disappears until the modern language, being replaced by the verbal quantifier mai mult 'much more'. In other Romance languages (French, Italian, Spanish) the same item (Fr. plus, It. più, Sp. más) is used not only in verbal contexts, but also in the adjectival phrase, cumulating (accomplishing simultaneously) the verbal quantifier and the degree marker function (Zafiu, 2006, p. 217). The data in (4a-f) from old Romanian show that the difference between old Romanian and old Romance, related to the function and status of the degree marker, was not obvious (in contrast to the present-day language, see Zafiu, 2006, p. 218).

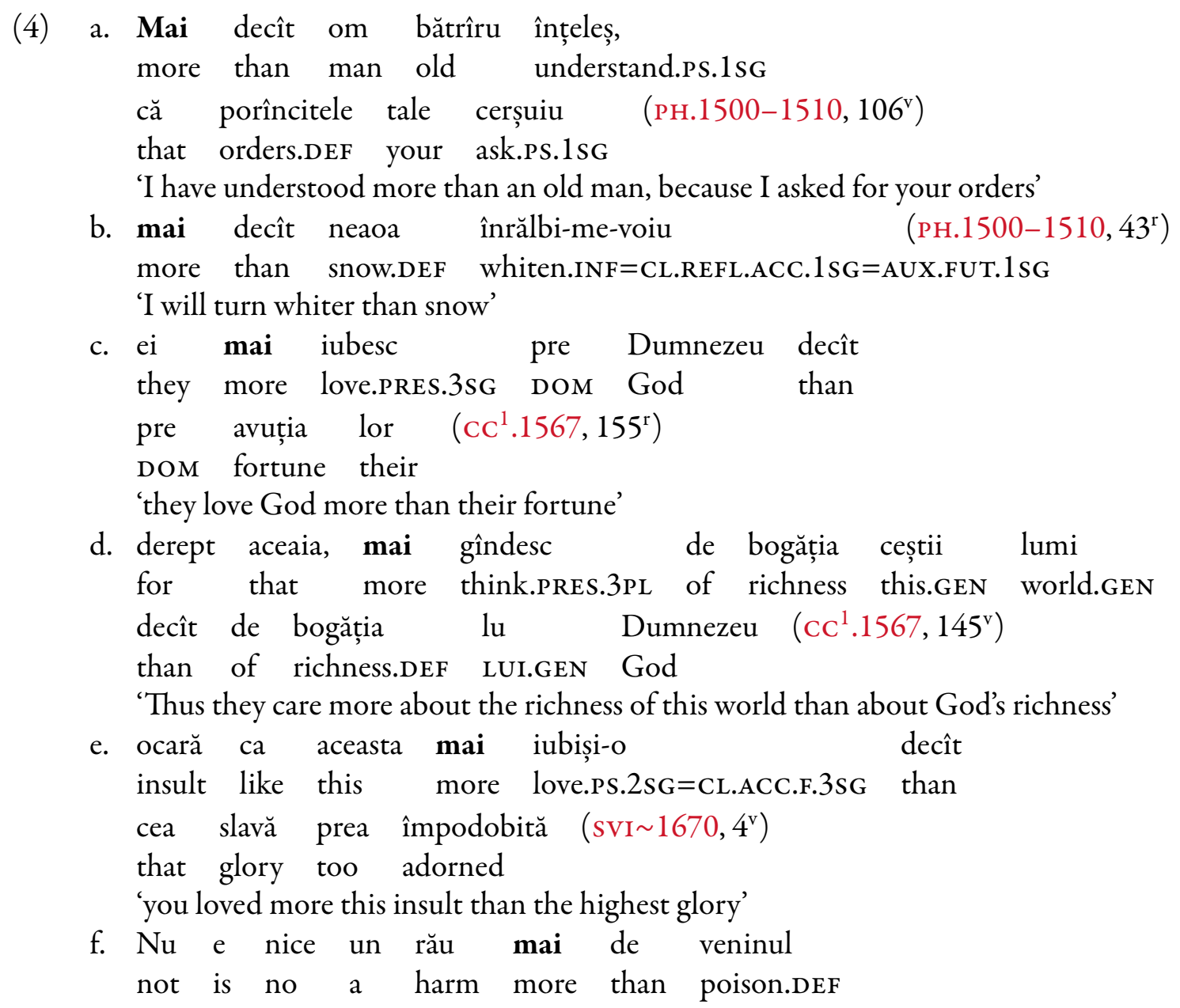


şarpelui $\quad($ FD.1592-604, 471 $)$

snake.DEF.GEN

'There is no stronger harm than the serpent's poison'

Mai and camai are attested as semi-adverbs/adverbial clitics with an additive temporal value ('again, one more time, already, still') since the first attested texts $(5,6)$. But while the first one is still very productive in the modern language, the last one gradually disappeared:

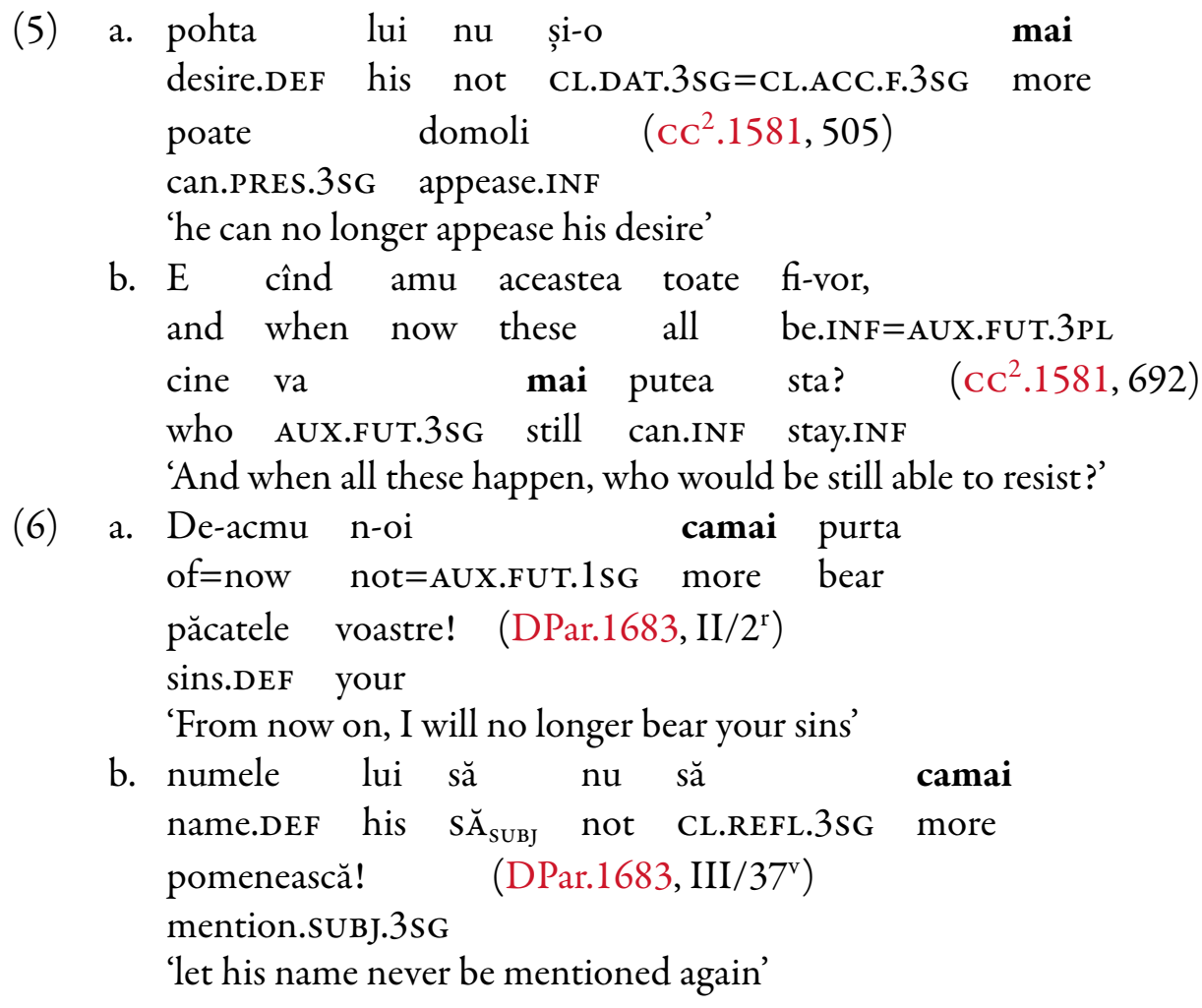

In non-verbal contexts, mai functions as a weak non-clitic adverb, with a stronger degree of deficiency ${ }^{4}$ than other weak adverbs. In adverbial contexts, mai functions as an adverbial clitic. The delimitation of clitic adverbs from weak non-clitic ones is based on syntactic features, among which word order is the most important.

\section{The clausal realizations of the comparative complement}

The comparative complement represents the standard of comparison in a comparative structure. Given that it is obligatorily expressed and it is licensed in a binary syntactic configuration, it has been interpreted in recent work (GALR, II; GBLR) as a complement to the degree marker (not as a manner adjunct, as in the traditional literature). Generally, the comparative complement has an elliptical structure, originating in a reduced clause, from which one or more chunks are preserved (GALR, II, p. 473-485). Moreover, many typological studies underline the complexity of comparative structures (which are based on ellipsis and reorganization) and the multiple interpretations of these constructions (Pană Dindelegan, 2003; Zafiu, 2006).

The comparative complement is licensed by the degree operator (Cornilescu, 2008) and it is prototypically realized as a PP headed by the prepositions ca, decit 'than', de 'among.' There is no locality constraint,

\footnotetext{
${ }^{4}$ The difference related to (phonological, morphological, semantic or syntactic) deficiency between clitics and weak adverbs was thrown into light by Reinheimer Rîpeanu (2004), in the analysis of mai 'more', cam 'still', prea 'too', tot 'continuously', $s i$ 'also'. For the analysis of the different types of mai in the old language, see also Donazzan \& Mardale (2010); Mîrzea Vasile (2012, p. 129-151); Brăescu (2017, p. 79-96).
} 
the adjective or other items being able to intervene between the degree operator and the comparative complement.

The structures with comparative of inequality complements showed a high degree of variation since Latin with respect to the marking of the comparative complement (ILR, p. 266; Stoica, 2015). It was realized by analytical means, with quam (7a) or by synthetic ones, i.e. the ablative case (7b). These structures were not in free variation but rather in complementary distribution: the ablative was preferred in idioms, in negative structures and in rhetorical questions (Ledgeway, 2012, p. 23). The synthetic comparative complement was replaced in Late Latin by new analytical structures with the preposition $a b$, and especially with $d e+$ accusative / ablative (7c):

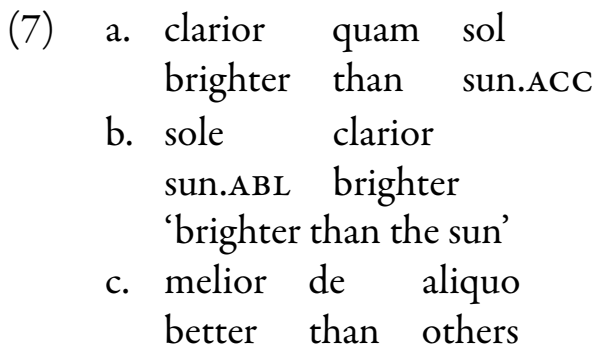

In the analytic pattern preserved in the Romance languages, the prepositional phrase has different realizations. The construction with quam $(>c a)$ is preserved in old Portuguese, in old Italian varieties and in Romanian (Salvi, 2011, p. 338) but was replaced with the que / che, de / di structure of with new analytical forms: Rom. decit, It. di quanto, Sp. de lo que, Port. do que.

In the earliest attested Romanian texts, we found comparative complements realized ad prepositional phrases headed by decit (8) and de (9). The comparative of inequality markers are frequently in free competition (10) and it is impossible to identify the syntactic constraints governing their usage ${ }^{5}$ (Ciompec, 1985, p. 156; Ciobanu, 2007; Stan, 2013).

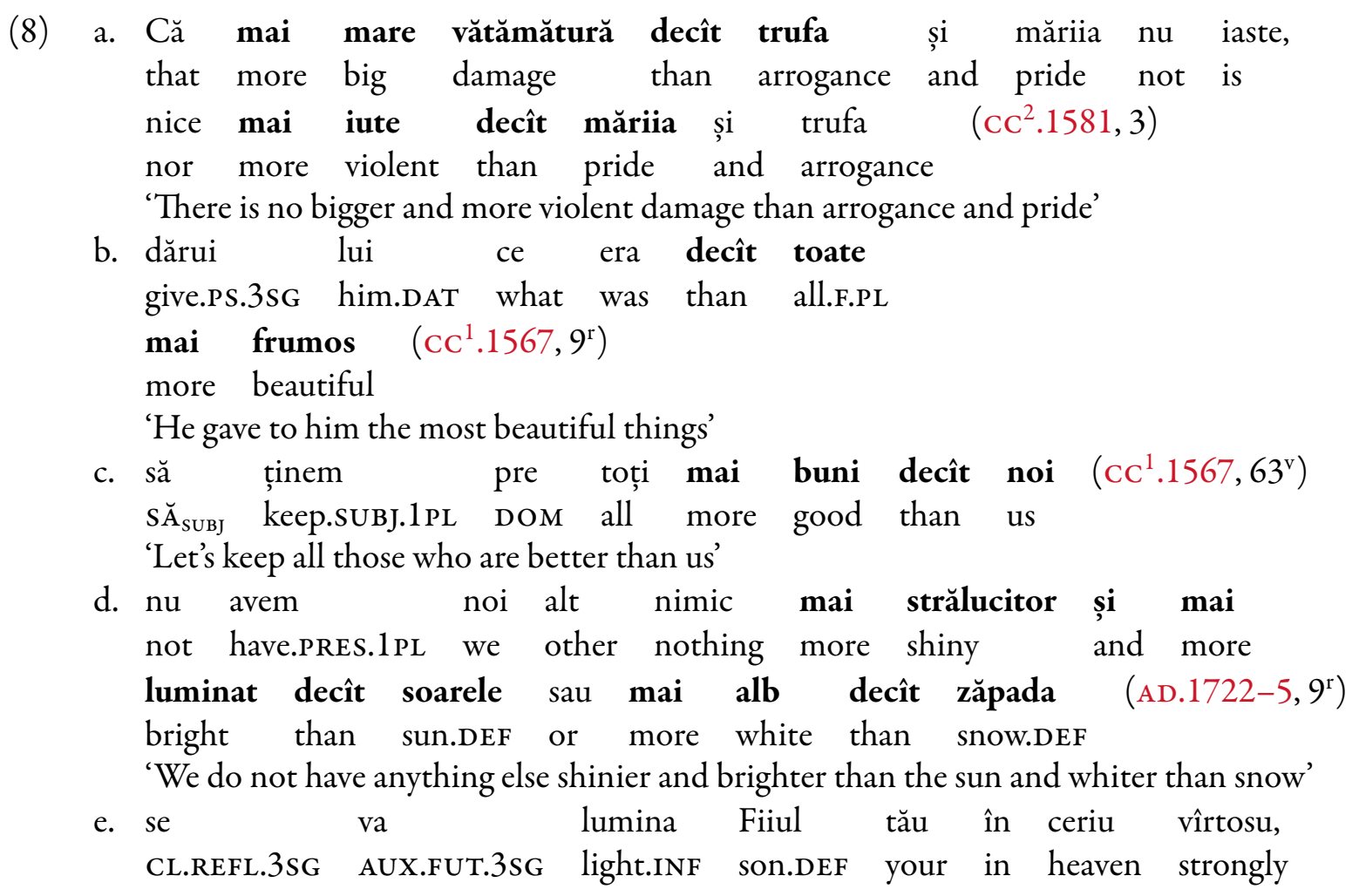

\footnotetext{
${ }^{5}$ It was noticed (Ciobanu, 2007, p. 170) that the old texts from the $16^{\text {th }}$ century (CV.1563-8, CT.1560-1, PO.1582), as well as later texts (such as NT.1648, A.1620) prefer the construction with de. In other texts (such as CC ${ }^{2} .1581$ ) the construction with decitt is preferred. In letters and original documents, the construction with de is rare and the one with decit is not attested.
} 
mai luminosu de şapte ori decît soarele $\left(\mathrm{CS}_{\mathrm{IV}} .1590-602,18^{\mathrm{v}}\right)$

more bright of seven times than sun.DEF

'Your Son will strongly light up in Heaven, brighter than the sun'

f. cu mai multă trudă înjugată iaste, decît

with more much effort yoke.F.sG is than

cu veselie $\left(\mathrm{CC}^{2} .1581,27\right)$

with joy

'She is yoked with more effort than joy'

(9)

a. Aduceți-vă aminte de cuvînt ce eu am

bring=CL.REFL.DAT.2PL in.mind of word that I AUX.PERF.1sG

zis voao: că nu iaste robul mai mare

say.PPLE you.PL.DAT that not is slave.DEF more great

de domnu-său $\left(\mathrm{CC}^{2} .1581,256\right)$

than master $=$ his

'Remember what I have said to you, that the slave is not greater than his master'

b. oaminii ficiorilor lu Izdrail mai mulți-s

people.DEF sons.DEF.GeN LUI.GeN Israel more many=are

și mai tari de noi (PO.1582, 180)

and more strong of us

'The people of Israel's sons are more numerous and stronger than us'

c. du-te delamine, că de mine cu mult

go.IMP.2SG=CL.REFL.ACC.2sG from me that than me with a.lot

mai putearnic te-ai făcut (PO.1582, 86)

more strong CL.REFL.ACC.2SG=AUX.PERF.2SG become.PPLE

'You shall leave me, because you became much stronger'

d. că mai frumoasă fată de aceasta

that more beautiful girl than this

n-am vădzut $\left(\mathrm{CS}_{\mathrm{XI}} \cdot 1583-619,91^{\mathrm{v}}\right)$

not $=$ AUX.PERF.1SG see.PPLE

'that I have never seen a more beautiful girl than this one'

e. nu vă teamereți amu, de multe pasări

not CL.REFL.ACC.2PL be.afraid.IMP now than many birds

mai buni seți voi $\left(\mathrm{CC}^{1} .1567,129^{\mathrm{v}}\right)$

more good are you.PL

'You should not be afraid, you are better than many other birds'

f. Dup-aceea le va da cununi în capul loru, after=that CL.ACC.3PL AUX.FUT.3SG give.INF crowns in head.DEF their

mai luminate de soarele $\left(\mathrm{CS}_{\mathrm{V}} .1590-602,47^{\mathrm{v}}\right)$

more bright.F.PL than sun.DEF

'Afterwards, he will give them crowns on their heads, brighter than the sun'

(10) a. în ceastă lume să nu aibi nemică de să-ți

in this world $\breve{S}_{\text {SUBJ }}$ not have nothing which $s \breve{A}_{\text {SUBJ }}=C L . D A T .2 S G$

fie mai drag și mai scump decît Dumnezeu, de

be more dear and more valuable than God that

să nu iubești mai vîrtos de Dumnezeu

SA $\breve{A B B J}_{\text {SU }}$ not love.PREs.2SG more strong than God

nece tată-tău, nece mumă-ta $\left(\mathrm{CC}^{1} .1567,132^{\mathrm{v}}\right)$

neither father=your nor mother=your 
'In this world you should have nothing more dear and more valuable than God, you should not love your father and your mother more than you love God'

b. mai închinată și mai fericită ca o împărăteasă

more glorified.F and more happy.F than an empress

a lumii, de toți credincioșii pămîntului și

of world.DEF.GeN than all believers.DEF earth.DEF.GEN and

sub bezne mai strașnică și mai înfricoșată

under darkness.PL more strong.F and more frightening.F

asupra dracilor decît toți sfinţii (AD.1722-5, 16 $)$

against devil.PL.GEN than all saints.DEF

'More glorified and happier than an empress of the world, stronger in darkness than all the believers on earth and more frightening for devils than all the saints'

In numerous comparative structures (including adverbs), the two parts of decitt (the preposition de and the adverb cit) are not merged (11). Moreover, the merger is only a written convention, without other consequences:
a. feace
ciudă
mai
mare și mai
minunată
makes
astonishment more
big and more
wonderful
de cît toate ciudesele $\left(\mathrm{CC}^{2} .1581,109\right)$
than all miracles.DEF
'he produces more astonishment than all the miracles'
b. Că era și mai prost mai vîrtos de cît alalți $\left(\right.$ CC $\left.^{2} .1581,297\right)$
that was and more ignorant more strong than others
'That he was more ignorant than the others'
c. spăla-mă-vei și mai vîrtos de cît zăpada
wash.INF $=$ CL.ACC.1SG $=$ AUX.FUT.2SG and more strong than snow.DEF
mă voi albi (DDL.1679, 208)
CL.REFL.ACC.1SG AUX.FUT.1SG whiten.INF
'You will wash me and I will turn whiter than snow'

The prepositional value of decit is interpreted (Cornilescu, 2008) as form of variation or as an oscillating form in the terms of the re-analysis framework (through the change in the grammatical function). The author adopts Haspelmath's (1998) definition of re-analysis: the different interpretation associated to the same chain from the point of view of the constituency or of the syntactic categories of the constituents, a process which takes place in the passage from one generation to another.

The comparative construction with de is preserved from Late Latin (Densusianu, 1938, p. 380-381; Rosetti, 1986, p. 512; Ciompec, 1985, p. 156). A syntactic feature of the preposition de in comparative structures is that it selects a noun with a definite article $(12 \mathrm{a}, \mathrm{b})$, without other constituents subordinated to the noun (Stan, 2013). In contradistinction, the preposition decit selects a noun without article (12c,d):

a. [Hristos] aceastea toate făcea-le

Christ these all make.IMPERF.3SG=CL.ACC.F.3PL

mai vîrtos de omul $\left(\mathrm{CC}^{2} .1581,272\right)$

more strong than people.DEF

'Christ made all these things more than people did'

b. Iară Domnul arătă că și de vulpile și

and God shows that and than foxes.DEF and

de pasările mai sărac iaste $\left(\mathrm{CC}^{2} .1581,277\right)$

than birds.DEF more poor is

'And God shows that he is poorer that foxes and birds' 
c. trupul mai slab iaste decît suflet $\left(\mathrm{CC}^{2} .1581,424\right)$ body.DEF more weak is than soul 'the body is weaker than the soul'

d. Mai bunu-i ospățul cu verdeață de prieteșug și more good=is meal.DEF with greens of friendship and de har decît vițel de iasle cu vrajbă (DPar.1683, III/7) of grace than veal of manger with brawl 'The meal of greens with friendship and grace is better than eating veal with brawl'

In the present-day system of comparison, de limited its values and specialized for expressing measure phrases (Niculescu, 1999, p. 186), while decît extended its usage and took over the comparative complement (Stan, 2013, p. 310; GR, p. 506).

In later texts from the $17^{\text {th }}$ century $c a$ is also attested (Frâncu, 2009, p. 198; Ciobanu, 2007); in the $16^{\text {th }}$ century, it was used only sporadically $(13 \mathrm{a}, \mathrm{b})$, a fact which suggest that it was in an incipient stage of grammaticalization (see also Niculescu, 1999, p. 187-188; Stan, 2013, p. 311). The structure with the preposition $c a$ was considered non-standard at the beginning, "a completely misguided Wallachian provincialism" (Tiktin, 1945, p. 68). The preference for the construction with decit is supported by latter work: "very often, decit is replaced by $c a$ in the spoken language and even in the literary language. Educated speakers and good writers avoid this construction" (Iordan et al., 1967, p. 115).
a. la noi nice un lucru nu-i mai bun și mai cufolos ca at us no a thing not=is more good and more useful than ceaea cînd murim pentru credința cea bună (Dvs.1682-6, 15v) that when die.PREs.2PL for faith.DEF that good.F 'For us, no other thing is better and more useful than when we die for the good faith'
b. Și nu iaste alta mai defolos și mai înfrîmsețată, and not is other more useful and more beautiful ca dragostea ceaia nefățarnica $\left(\mathrm{CC}^{2} .1581,140\right)$ than love.DEF that sincere 'And there is nothing else more useful and more sincere than sincere love'

Another comparative of inequality structure involves an incomplete pattern, in which the comparative complement is absent (14a). In these contexts, the comparative complement is contextually recovered. In the old language, another elliptical pattern is attested: mai is missing but the comparative complement is overtly realized. The attestation of this pattern, which disappeared from the present-day language, proves that the co-occurrence of the comparative complement and the degree operator was not obligatory in the old language (Ciompec, 1985, p. 162) (14b,c):
a. atunce el în mai mare grije iaste $\left(\mathrm{CC}^{2} .1581,79\right)$ then he in more big concern is 'then he is more concerned'

b. Bunru e mie leagea rrostului tău decît good is me.DAT law.DEF mouth.DEF.geN your than o mie de aur și de argint (PH.1500-1510,105 ${ }^{\mathrm{r}}$ one thousand of gold and of silver 'For me, your law from your mouth is more important than one thousand pieces of gold and silver'
c. ca o sfîntă ce iaste decît toții sfinţii like a sacred.F which is than all saints.DEF 'like a saint which is more sacred than all the saints' 
In many structures from the old texts (15) a sort of generalized comparison (Ciompec, 1985, p. 164) is realized; this structure resembles the superlative one and included a prepositional complement headed by dentre / dentru 'among' (15a), preste 'over' (15b), pre 'on' (15c):
a. Că adică și dentru îngeri, carele era mai mare, that that.is and from angels which was more great trufa-l lepădă den ceriu $\left(\mathrm{CC}^{2} .1581,3\right)$ pride. $\mathrm{DEF}=\mathrm{CL} . \mathrm{ACC} . \mathrm{M} .3 \mathrm{sg}$ throw.PS.3SG from Heaven 'That is, even of the angels, that who was greater was expelled from Heaven'
b. fu be.Ps.3sG more great above all in house.DEF her 'she was greater above all in her house'
c. mai mare e și mai înraltu e pre toți more great is and more high is over all oamenrii $\quad\left(\mathrm{PH} .1500-1510,81^{\mathrm{v}}\right)$ people.DEF 'he is the greater and higher than all the people'

\section{Word order in comparative structures}

Besides the canonical word order of the present-day language [operator + adjective + comparative complement (16a)], in the old language there are also numerous structures with pre-adjectival complements (16b-e) (Brăescu et al., 2015). These constructions, with pre-adjectival comparative complements, still attested in poetry and folkloric texts from the $19^{\text {th }}$ century, have been preserved in the present-day language (16f) only in the religious, obsolete register (Zafiu, 2006, p. 217):
a. Că altă moarte nu era mai spurcată şi mai fără that other death not was more mean and more without de cinste decît răstignitura $\left(\mathrm{CC}^{2} .1581,68\right)$ of honesty than crucifixion.DEF 'That there was no other death meaner and more unfair that crucifixion'
b. decît un iepure mai slabă şi mai pemintiană than a rabbit more weak and more earthly
c. decît stîrvul împuțit tot mai dulce iaste (CII 1705, 38) than carrion.DEF putrid still more sweat is 'he is still sweater than the putrid carrion'
d. Decît credința și nădejdia iaste mai mare than faith.DEF and hope.DEF is more big dragostea (AD.1722-5, 22 $\left.{ }^{\mathrm{r}}\right)$
love.DEF
'Love is bigger than faith and hope'

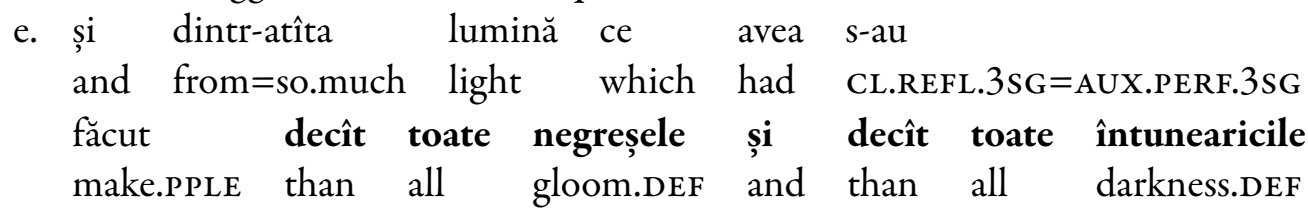




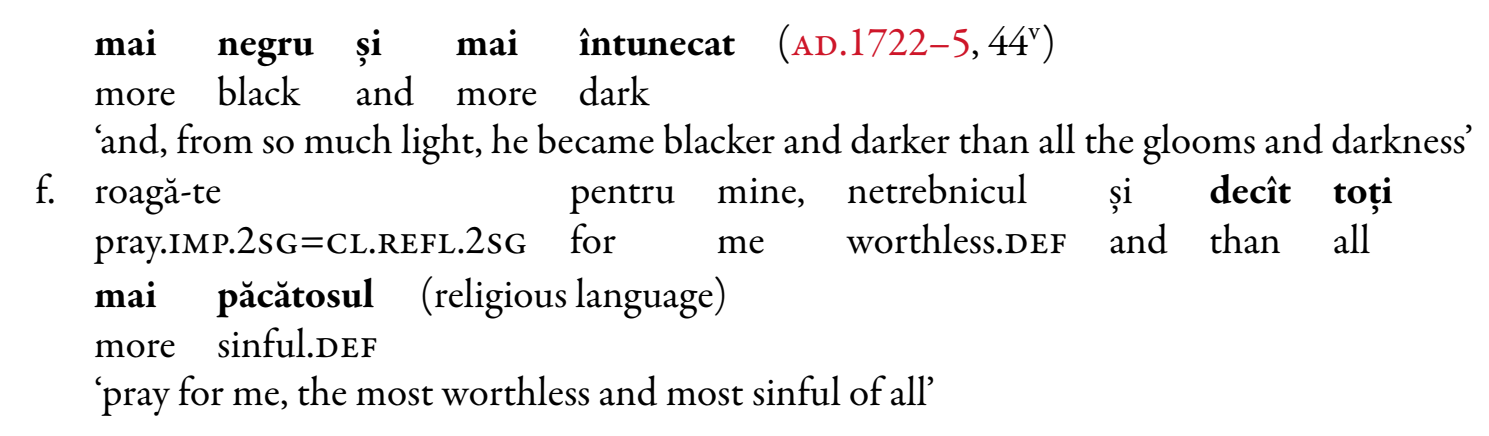

The structures with pre-adjectival complements are also attested in other old Romance languages, for example in old Italian (Giusti, 2010, p. 596-598; Poletto, 2014, p. 76). These configurations have been associated (Ledgeway, 2012; Brăescu et al., 2015; Brăescu \& Dragomirescu, 2017) with the discontinuous structures and related to the existence of certain relics of the non-configurational syntax in old Romanian, preserved from Latin. The disappearance of the structures under $(16 b-e)$ should be explained by an ongoing change in the setting of the head directionality parameter, from partial head-final to consistently head-initial and by establishment of a fully-fledged configurational syntax, in which the relations between constituents are encoded by word order.

To explain the ordering of heads and complements (the variation between head-initial and head-final structures), Ledgeway (2012) employs roll-up movement: the so-called free word order of Latin is to be explained by the roll-up movement, whereas the more rigid word order of the Romance languages is determined by the elimination of this type of movement.

In this light, the changes taking places in the passage from Latin to the Romance languages no longer appear to be so radical (Brăescu et al., 2015): Latin was a language in which the innovative head-initial syntax and the archaic head-final one were in competition (Ledgeway, 2012), a situation which carried over to old Romance (at least to old Romanian and to old Italian); the complete change from a bead-final syntax to head-initial syntax was brought to a close in modern Romance. Expectedly, the old Romance languages (old Romanian included) were more similar to Latin in the domain of word order.

\section{Conclusions}

In diachrony, the comparative of superiority constructions, defined as complex structures expressing a relation between a property and a standard of comparison, are attested in different syntactic configurations. In this paper, we have analysed old Romanian texts with respect looking at three aspects: the grammaticalization path of the operator mai, the clausal realizations of the comparative complement, and word order in comparative structures.

The specialization of the operator mai to express the comparative of superiority was favoured by many processes characterizing the $16^{\text {th }}$ and the $17^{\text {th }}$ centuries: the disappearance of the competing form camai and the loss of the manner adverb mai. The competition between forms with the same function used in similar contexts and without any clear constraint represents a feature specific to all the degree operators and, actually, it is a state of all emerging systems.

The comparative complement in comparative of superiority structures was realized analytically in the old language, by means of several prepositional constructions. We have analyzed the distribution of the constructions with de 'of', decit and ca 'than'. The emergence of the analytical expressions (Ledgeway, 2012) illustrates a general tendency of all the weakened synthetic structures, which were to be progressively replaced by other competing structures and to undergo grammaticalization.

As far as the word order of the comparative complements is concerned, we have paid special attention to the "deviant" pattern, different from the one of the present-day language, the pattern with a preadjectival comparative complement. We have accounted for these structures using Ledgeway's (2012) insights, according to which the passage from Latin to Romance is characterized by an on-going passage 
from a head-final syntax to a head-initial one, concomitant with the establishment of a fully configurational syntax. In the older stages of Romanian, in which numerous structures were in competition, word order was freer than in the present-day language.

\section{Bibliography}

\section{A. Corpus}

A.1620 = Alexandria, în Zgraon, Fl. (ed.), Cele mai vechi cărți populare în literatura română, vol. 11, Fundația Națională pentru Știință și Artă, București, 2006.

AD.1722-5 = Antim Ivireanul, Didahii, în Antim Ivireanul, Opere, ed. G. Ștrempel, Editura Minerva, București, 1972, p. 1238.

Bв.1688 = Biblia adecă Dumnezeiasca Scriptură a Vechiului și Noului Testament, tipărită întîia oară la 1688 în timpul lui Șerban Vodă Cantacuzino, Domnul Țării Românești, Editura Institutului Biblic, București, 1977.

$\mathrm{CC}^{1} .1567=$ Coresi, TîlculEvangheliilor, în Coresi, Tîlcul evangheliilor șimolitvenic românesc, ed. V. Drimba, Editura Academiei Române, București, 1998.

$\mathrm{CC}^{2} .1581$ = Coresi, Cartea cu învățătură, în Diaconul Coresi, Carte cu învățătură (1581), vol. I, Textul, ed. S. Pușcariu \& Al. Procopovici, Atelierele Grafice Socec, București, 1914.

CII 1705 = Dimitrie Cantemir, Istoria ieroglifică, în D. Cantemir, Opere complete, IV. Istoria ieroglifică, ed. S. Toma, Editura Academiei, București, 1974.

$\mathrm{CS}_{\mathrm{IV}, \mathrm{v}}$. 1590-602, $\mathrm{CS}_{\mathrm{XI}}$. 1583-619 = Chivu, Gh. (ed.) (1993). Codex Sturdzanus, Editura Academiei Române, București.

CT.1560-1 = Coresi, Tetraevanghel, în Dimitrescu, Fl. (ed.) (1963). Tetraevanghelul tipărit de Coresi, Brașov, 1560-1561, comparat cu Evangheliarul lui Radu de la Mănicești, 1574, Editura Academiei, București.

Cv.1563-83 = Codicele Voronețean, ed. M. Costinescu, Editura Academiei Române, București, 1981.

DDL.1679 = Dosoftei, Dumnezăiasca liturghie, ed. N. A. Ursu, Mitropolia Moldovei și Sucevei, Iași, 1980.

DPar.1683 = Dosoftei, Parimiile preste an, 1683, ed. M. Ungureanu, Editura Universității „Alexandru Ioan Cuza”, Iași, 2012. DVs.1682-6 = Dosoftei, Viața și petreacerea svinților, Iași.

FD.1592-604 = Floarea darurilor, în Roman Moraru, Al. (ed.) (1996). Cele mai vechi cărți populare în literatura română, 1,

Editura Minerva, București, p. 119-182.

NT.1648 = Noul Testament, Editura Reîntregirea, Alba Iulia, 1998 .

PH.1500-1510 = Psaltirea Hurmuzaki, ed. I. Gheție \& M. Teodorescu, Editura Academiei Române, București, 2005.

Po.1582 = Palia de la Orăștie, ed. V. Pamfil, Editura Academiei RSR, București, 1968.

SVI 1670 = Varlaam și Ioasaf, în Stanciu Istrate, M. (2013). Reflexe ale medievalității europene în cultura română veche: Var-

laam și Ioasaf în cea mai veche versiune a traducerii lui Udrişte Năsturel, Editura Muzeului Naţional al Literaturii Române, București.

\section{B. References}

Brăescu, R. (2015). Gradarea în limba română. Perspectivă istorică și tipologică, Editura Muzeul Literaturii Române.

Brăescu, R., Dragomirescu, A. \& Nicolae, Al. (2015). (Non-)configurationality and the internal syntax of adjectives in old Romanian, in "Bucharest Working Papers in Linguistics", vol 17, nr. 2, p. 55-74.

Brăescu, R. (2017). Mărci de comparație în textele vechi, in Dragomirescu, A., Nicolae, Al., Stan, C. \& Zafiu, R. (eds), Sintaxa ca mod de a fi. Omagiu Gabrielei Pană Dindelegan, la aniversare, Editura Universității din București, București, p. 79-86.

Brăescu, R. \& Dragomirescu, A. (2017). (Non) configuraționalitate în sintaxa adjectivului din româna veche, in "Actele celui de-al VI-lea Simpozion internațional de lingvistică", in print.

Ciobanu, F. (2007). Complementul, in Avram, M. (ed.), Sintaxa limbii române în secolele al XVI-lea - al XVIII-lea, Editura Academiei Române, București, p. 117-188.

Ciompec, G. (1985). Morfosintaxa adverbului românesc, Editura Științifică și Enciclopedică, București.

Cornilescu, A. (2008). Reanalizăşsigramaticalizare: structura lui decît, in Pană Dindelegan. G. (ed.), Limba română - dinamica limbii, dinamica interpretării, Editura Universității din București, București, p. 203-212.

Densusianu, O. (1938). Histoire de la langue roumaine, vol. II, Ernest Leroux, Paris. Ed. rom.: Istoria limbii române, ed. J. Byck, Editura Științifică, București, 1961.

Donazzan, M. \& Mardale, Al. (2010). Additive and aspectual adverbs: towards an analysis of Romanian mai, in "Revue roumaine de linguistique", 3, p. 247-269.

Frâncu, C. (2009). Gramatica limbii române vechi (1521-1780), Casa Editorială Demiurg, Iași.

GALR = Guțu Romalo, V. (coord.) (2008). Gramatica limbii române, I. Cuvîntul, II. Enunțul, Editura Academiei, București ( $1^{\text {st }}$ edition: 2005).

GBLR = Pană Dindelegan, G. (ed.) (2010). Gramatica de bază a limbii române, Editura Univers Enciclopedic, București.

Giusti, G. (2010). Il sintagma aggettivale, in Salvi, G. \& Renzi, L. (eds), Grammatica dell'italiano antico, Il Mulino, Bologna, p. 593-615. 
GR = Pană Dindelegan, G. (ed.) (2013). The Grammar of Romanian, Oxford University Press, Oxford.

Haspelmath, M. (1998). Does grammaticalization need reanalysis?, in "Studies in Language", 22, p. 315-351, Crossref.

ILR = Graur, Al. (ed.) (1965). Istoria limbii române, I, Editura Academiei, București.

Iordan, I., Guțu Romalo, V. \& Niculescu, Al. (1967). Structura morfologică a limbii române contemporane, Editura Științifică, București.

Kennedy, C. (1999). Projecting the adjective: the syntax and semantics of gradability and comparison, Garland Press, New York, Crossref.

Lapesa, R. (1981). Historia de la lengua española, Gredos, Madrid.

Ledgeway, A. (2012). From Latin to Romance. Morphosyntactic Typology and Change, Oxford University Press, Oxford, Crossref.

Lüder, E. (1996). Procedee de gradație lingvistică, Editura Universităţii „Alexandru Ioan Cuza”, Iaşi.

Mîrzea Vasile, C. (2012). Eterogenitatea adverbului românesc, Editura Academiei Române, București.

Niculescu, A. (1999). Individualitatea limbii române între limbile romanice, vol. III, Editura Clusium, Cluj-Napoca.

Pană Dindelegan, G. (2003). Elemente de gramatică. Dificultăți, controverse, noi interpretări, Editura Humanitas, București.

Pană Dindelegan, G. (ed.) (2016). The Syntax of Old Romanian, Oxford University Press, Oxford, Crossref.

Poletto, C. (2014). Word Order in Old Italian, Oxford University Press, Oxford, Crossref.

Reinheimer Rîpeanu, S. (2004). Intensification et atténuation en roumain. Les adverbes cam, mai, prea, şi, tot, in Araujo Carreira, M.H. (ed.), Intensification et atténuation dans les langues romanes, Université Paris 8 Vincennes - Saint Denis, p. 225-246.

Rosetti, A. (1986). Istoria limbii române de la origini pînă la inceputul secolului al XVII-lea, Editura Științifică și Enciclopedică, București; ed. I-a: 1938.

Salvi, G. (2011). Morphosyntactic Persistence, in Maiden, M., Smith, J.C. \& Ledgeway, A. (eds), The Cambridge History of the Romance Languages, I. Structures, Cambridge University Press, Cambridge / New York, p. 318-381, Crossref.

Stan, C. (2013). O sintaxă diacronică a limbii române vechi, Editura Universității din București, București.

Stoica, G. (2015). The Adjectival Category of Intensity. From Latin to Proto-Romanian, in Pană Dindelegan, G., Zafiu, R., Dragomirescu, A., Nicula, I., Nicolae, Al. \& Esher, L. (eds), Diachronic Variation in Romanian, Cambridge Scholars Publishing, Newcastle upon Tyne, p. 123-150.

Tiktin, H. (1945). Gramatica română, $3^{\text {rd }}$ edition, revised by I.-A. Candrea, Editura Tempo, București $\left(1^{\text {st }}\right.$ edition: 18931895).

Zafiu, R. (2006). Construcții comparative, in Pană Dindelegan, G. (ed), Limba română - Aspecte sincronice și diacronice, Editura Universității din București, București, p. 215-222. 